\title{
Development and application of a one-step low cost procedure to concentrate viruses from seawater samples.
}

Authors: B. Calgua ${ }^{1}$, A. Mengewein ${ }^{2}$, A. Grünert ${ }^{2}$, S. Bofill-Mas ${ }^{1}$, P. ClementeCasares $^{1}$, A. Hundesa ${ }^{1}$, A.P. Wyn-Jones ${ }^{3}$, J.M. López-Pila², R. Girones ${ }^{1 *}$.

${ }^{1}$ Department of Microbiology, University of Barcelona, Av. Diagonal, 645, 08028 Barcelona, Spain.

${ }^{2}$ German Environmental Agency (Umweltbundesamt), WörlitzerPlatz 1, 06844 DessauRoßlau, Berlin, Germany

${ }^{3}$ I.G.E.S., University of Aberystwyth, Aberystwyth, SY23 3DB, Wales, U.K.

Running title: One-step procedure to concentrate human adenoviruses in seawater.

*Corresponding author: Department of Microbiology, Faculty of Biology, University of Barcelona, Av. Diagonal 645, Barcelona 08028, Spain.

Telephone number: +34 93 4039043; Fax number: +34 934039047. 


\begin{abstract}
A novel and simple procedure for concentrating adenoviruses from sea water samples is described. The technique entails the adsorption of viruses to pre-flocculated skimmed milk proteins, allowing the flocs to sediment by gravity, and dissolving the separated sediment in phosphate buffer. Concentrated virus may be detected by PCR techniques following nucleic acid extraction. The method requires no specialized equipment other than that usually available in routine public health laboratories, and due to its straightforwardness it allows the processing of a larger number of water samples simultaneously. The usefulness of the method was demonstrated in concentration of virus in multiple seawater samples during a survey of adenoviruses in coastal waters.
\end{abstract}

Keywords: adenovirus, seawater, flocculation, concentration method, QPCR. 


\section{INTRODUCTION}

Surveillance of coastal waters, for recreation, cultivation of shellfish, or other activities with relevance for human health, includes monitoring for faecal pollution. While any pollution might pose a health risk for humans, faecal pollution from human sources presents a particular hazard since it might contain pathogens that specifically infect humans. Although detection of the conventional faecal pollution indicators, E. coli and intestinal enterococci, is straightforward, occurrence of bacterial indicators does not necessarily correlate with the presence of viral pathogens that are more stable than bacteria in the environment, nor do bacterial indicators provide information on the potential origin of the contamination. Several workers have reported substantial levels of pathogenic viruses in bathing waters complying with local public health regulations (Gerba et al., 1979; Goyal et al., 1984; Griffin et al., 1999; Jiang et al., 2001 and Noble and Fuhrman, 2001). In addition, epidemiological studies carried out to estimate the health risk of swimming in bathing waters have suggested that the gastroenteritis burden of bathers which is attributable to the presence of viruses is detected at concentrations of bacterial indicators well below statutory standards (Griffin et al., 2003 and Lipp et al., 2001).

There is therefore a public health requirement for additional parameters that indicate the presence of viruses in bathing waters and shellfish-growing areas more reliably. Human adenoviruses (HAdV) have been proposed to fill this gap both as indicators and as source tracking organisms (Fong and Lipp, 2005 and Hundesa el al., 2006), since several studies have reported that HAdV have a high stability under environmental stress, such as UV radiation, temperature, chlorine concentration and $\mathrm{pH}$ variation, including sewage treatment procedures (Carter, 2005; Fong and Lipp, 2005; Pina et al., 1998). Moreover, the levels of HAdV found in sewage match the numbers of the usual 
faecal indicator E. coli (EC), and might outnumber intestinal enterococci (IC) (BofillMas et. al., 2006 and Wolf, 2005). Therefore the development of a simple efficient method for the concentration and quantitation of HAdV is of high interest in respect of indicators, of instruments for source tracking of faecal pollution, and for carrying out risk assessment studies of polluted coastal waters, which, in the European Union, comprise more than 14200 out of about 21000 registered bathing water sites.

Detection of viruses in low or moderately polluted waters calls for the concentration of the viruses from at least several litres of water into a much smaller volume (typically 1 000-fold concentration), a procedure that usually includes two consecutive concentration steps (1) electrostatic adsorption of the virus particles to a solid matrix followed by their elution with an alkaline proteinaceous solution (eluant, usually skimmed milk or beef extract solution), and (2) precipitation of the proteins to which any viruses are adsorbed from the eluant by lowering the $\mathrm{pH}$ ("organic flocculation"), and resuspending the flocculated protein in a small volume of neutral buffer. This somewhat cumbersome procedure significantly hampers larger scale virus-detection programs, not least because of its many steps and the need for several $\mathrm{pH}$ adjustments of the sample during concentration.

Following a surveillance investigation for detecting viruses in bathing waters (Virobathe, www.virobathe.org ) was observed that two-step procedures worked satisfactorily for freshwaters whereas their performance in recovering HAdV from coastal waters was less satisfactory.

A one-step protocol for the concentration of viruses from coastal waters was therefore developed based on the direct binding of the viruses to pre-flocculated skimmed milk proteins, thereby reducing the number of processing steps. The procedure described do not require the availability of specific equipment as filters or pressure pumps, 
commonly used for virus concentration from water, and represents a significant reduction in the cost of the assays. In this study are reported details of this protocol and its performance on a large scale study.

\section{MATERIALS AND METHODS}

\subsection{Virus and cell lines}

Adenovirus Type 2 NCPV \#00213 was used in this study as a positive control of the process. The virus titre was approximately $10^{4.3} \mathrm{PFU} \mathrm{mL}^{-1}$. The cell line A549 (ECACC, UK) was used to propagate the virus. A549 cells were grown in $175 \mathrm{~cm}^{2}$ flasks containing MEM medium (Life Technologies Ltd., Paisley, Scotland) supplemented with $10 \%$ (growth medium) or $2 \%$ (maintenance medium) heat inactivated foetal bovine serum (Life Technologies Ltd., Paisley, Scotland) and 100 units/mL penicillin, $10 \mathrm{mg} / \mathrm{mL}$ streptomycin and $2.5 \mu \mathrm{g} \mathrm{mL} \mathrm{m}^{-1}$ amphotericin B (Fungizone, Life Technologies Ltd., Paisley, Scotland).

\subsection{Water samples}

Three water types were used in this study. (i) Tap water from the metropolitan area of Berlin, Germany, seeded with raw strained wastewater to which was added, where indicated, artificial sea salts. (ii) Artificial seawater, prepared by adding $33.33 \mathrm{~g}$ artificial sea salts (Sigma, Aldrich Chemie GMBH, Steinheim, Germany), per liter of a 1:1 (v/v) mix of distilled and tap water from metropolitan area of Barcelona, which had been treated in a conventional municipal treatment plant. The mix was stirred until the salts were completely dissolved. (iii) Natural seawater from one sampling point in the 
coast near of metropolitan area of Barcelona collected at least at six meters from the shore and one meter from the surface.

The collection of samples for field studies was carried out based according to ISO 19458 (2006) for the collection of water samples for microbiological analysis.

Samples were stored for a maximum of $24 \mathrm{~h}$ at $4^{\circ} \mathrm{C}$ before being processed.

\subsection{Virus concentration by glass wool filtration.}

Ten liters of either tap water or artificial seawater were spiked with viruses (stock of adenoviruses or strained municipal raw wastewater), and concentrated by a glass wool column based in the study previously described by Vilaginès, et al. (1997). Briefly, viruses in 10L-water samples were concentrated by adsorption at $\mathrm{pH} 3.5$ to glass wool filters and eluted with beef-extract/glycine buffer at $\mathrm{pH} 9.5$ followed by organic flocculation at $\mathrm{pH} 4.5$. The flocs were pelleted by centrifugation at $7000 \mathrm{xg}$ for $30 \mathrm{~min}$ and the pellet was resuspended in $10 \mathrm{~mL}$ of PBS. Nucleic extraction was performed on this suspension as described in section 2.6.

\subsection{Virus concentration by skimmed milk (SM) flocculation procedure}

Pre-flocculated skimmed milk solution $(1 \% \mathrm{w} / \mathrm{v})$ was prepared by dissolving $10 \mathrm{~g}$ skimmed milk powder (Difco) in 1L artificial seawater and carefully adjusting the $\mathrm{pH}$ to 3.5 with $1 \mathrm{~N} \mathrm{HCl}$. One hundred $\mathrm{mL}$ of this solution were added to each of the previously acidified ( $\mathrm{pH}$ 3.5) 10L seawater samples (final concentration of skimmed milk $0.01 \% \mathrm{w} / \mathrm{v})$. Samples were stirred for eight $\mathrm{h} \mathrm{s}$ at room temperature and flocs were allowed to sediment by gravity for another eight hours. Supernatants were carefully removed using a vacuum pump without disturbing the sediment. The final volume of about $500 \mathrm{~mL}$ containing the sediment was transferred to a centrifuge pot and 
centrifuged at $7000 \mathrm{xg}$ for $30 \mathrm{~min}$ at $12^{\circ} \mathrm{C}$. Aliquots of the supernatants which had been suctioned previously were used to balance the pots. The supernatant was carefully removed and the pellet resuspended in $8 \mathrm{~mL}$ of $0.2 \mathrm{M}$ phosphate buffer at $\mathrm{pH} 7.5(1: 2$ $\mathrm{v} / \mathrm{v}$ of $\mathrm{Na}_{2} \mathrm{HPO}_{4} 0.2 \mathrm{M}$ and $\mathrm{NaH}_{2} \mathrm{PO}_{4} 0.2 \mathrm{M}$ ). Once the pellet was completely dissolved, phosphate buffer was added to a final volume of $10 \mathrm{~mL}$. The concentrate was stored at $20^{\circ} \mathrm{C}$.

\subsection{Detection of bacterial indicators and somatic coliphages}

The detection of IC, EC and somatic coliphages was carried out according to, ISO 7899-1 (1998); ISO 9308-3 (1998) and ISO 10705-2 (2000), respectively. The most probable number (MPN) technique was used to estimate the number of IC and EC /100 $\mathrm{mL}$ of sample according to standard methods and a plaque assay was used to estimate the concentration of somatic phages.

\subsection{Nucleic acids extraction from viral concentrates}

The NA extraction was performed with a NucleoSpin ${ }^{\circledR}$ RNA Virus F kit (Machery \& Nagel, Dueren, Germany), using $1 \mathrm{~mL}$ of the viral concentrate, NA being finally eluted in $100 \mu \mathrm{L}$ of elution buffer, or with a QIAamp Viral RNA kit (Qiagen), extracting $200 \mu \mathrm{L}$ of viral concentrate in $80 \mu \mathrm{L}$ of elution buffer. NA extracts were stored at $-20^{\circ} \mathrm{C}$ until analyzed by PCR.

\subsection{Quantitation and detection of HAdV}

Quantitation of HAdV genomes by QPCR was based on the assay previously described by Hernroth et al. (2002), which had been previously applied to the detection and quantitation of adenoviruses in shellfish samples (Formiga-Cruz et al., 2002), in river 
and drinking water (Albinana-Gimenez et al., 2006), in urban sewage, sludge and biosolids (Bofill-Mas et al., 2006). The method is based in a TaqMan ${ }^{\circledR}$ assay and uses two primers and a fluorogenic probe that recognize a fragment of the hexon gene of the HAdV genome. Amplification was performed in a $25-\mu \mathrm{L}$ reaction mixture containing $10 \mu \mathrm{L}$ of DNA and 12,5 $\mu \mathrm{L}$ of TaqMan ${ }^{\circledR}$ Universal PCR Master Mix, $0.9 \mu \mathrm{M}$ of each primer $(\mathrm{AdF}$ and $\mathrm{AdR})$ and $0.225 \mu \mathrm{M}$ of fluorogenic probe AdP1. TaqMan® Universal PCR Master Mix was supplied 2X concentrated and contained AmpliTaq Gold® DNA polymerase, dNTPs with dUTP, optimized buffer components and AmpErase ${ }^{\circledR}$ uracil$\mathrm{N}$-glycosylase. Following activation of the uracil-N-glycosylase $\left(2 \mathrm{~min}, 50^{\circ} \mathrm{C}\right)$ and activation of the AmpliTaq Gold for $10 \mathrm{~min}$ at $95^{\circ} \mathrm{C}, 40$ amplification cycles $(15 \mathrm{~s}$ at $95^{\circ} \mathrm{C}$ and 1 min at $60^{\circ} \mathrm{C}$ ) were performed with an $\mathrm{ABI} 7700$ detector system (Applied Biosystems).

Undiluted and ten-fold dilutions of the extracted DNA were run in duplicate (4 runs/sample). In all quantitative PCRs carried out the amount of DNA was defined as the mean of the data obtained. A non-template control and an amplification control were included in each run. The data produced by QPCR presented low variability in the diverse replicates. Significant variability was only observed in the results of a few undiluted samples probably due to the presence of inhibitors in the reaction, being these values excluded of the quantitation. The detection of HAdV genomes by nested PCR (nPCR) was based on studies by Allard et al. (2001), which has been previously applied to the detection of HAdV in urban sewage and shellfish (Formiga-Cruz et al., 2002 and Bofill-Mas et al., 2000) and in slaughterhouse, river and drinking water (AlbinanaGiménez et al., 2006 and Hundesa et al 2006). For the specific amplification of HAdV genomes, $10-\mu \mathrm{L}$ aliquots of the extracted nucleic acid were amplified by using a conventional nPCR test for amplifying a region of the HAdV hexon gene. 


\subsection{Sequencing of PCR products}

Products obtained after nPCR were purified with the QIAquick PCR purification kit (Qiagen). Both strands of the purified DNA amplicons were sequenced with the ABI PRISM $^{\mathrm{TM}}$ Dye Terminator Cycle Sequencing Ready Reaction kit with Ampli Taq ${ }^{\circledR}$ DNA polymerase FS (Perkin-Elmer, Applied Biosystems) following the manufacturer's instructions. The conditions for the 25-cycle sequencing amplification were: denaturing at $96^{\circ} \mathrm{C}$ for $10 \mathrm{~s}$, annealing at $50^{\circ} \mathrm{C}$ for $5 \mathrm{~s}$ and extension at $60^{\circ} \mathrm{C}$ for $4 \mathrm{~min}$. Primers for sequencing were used at $3.2 \mu \mathrm{M}$ concentration. The results were checked using the ABI PRISM 3730 XL automated sequencer (Perkin-Elmer, Applied Biosystems).

\subsection{Quality control of the amplification methods}

To reduce the probability of sample contamination by amplified DNA molecules, standard precautions were applied in all manipulations. Separate areas of the laboratory were used for reagents, treatment of samples, and manipulation of amplification products. All assays included negative controls. In all amplifications the mixture included uracil-DNA-glycosylase (UDG) (Invitrogen Corp., Carlsbad, USA) for degradation of amplified material that could contaminate the samples. Undiluted and a 10-fold dilution of the nucleic acid extract were analyzed in order to avoid false negatives because inhibition of the reactions.

\section{RESULTS}

\subsection{Kinetics of adsorption of HAdV to flocculated skimmed milk}


Two samples of $500 \mathrm{~mL}$ of artificial seawater sample was spiked with adenovirus type 2, and concentrated according to the SM-flocculation procedure. During stirring, six aliquots were collected at different times and the NA in each concentrate was extracted and analyzed by QPCR to determine the HAdV genome concentration. Figure 1 shows that after five hours the adsorption is essentially complete.

\subsection{Adenovirus recovery after concentration of natural seawater and artificial} seawater samples by applying the SM-flocculation procedure. Comparison with the two-step concentration procedure with glass wool and organic flocculation Three different sets of 10L-samples were used in these experiments. (i) Five artificial seawater samples were each seeded with HAdV containing $4.04 \times 10^{4}$ GC. (ii) Four natural seawater samples were each seeded with HAdV containing $6.91 \times 10^{4}$ HAdV GC. (iii) Five natural seawater samples were each seeded with HAdV containing $4.88 \times 10^{4}$ HAdV GC. All samples were concentrated using the SM-flocculation procedure and the concentrates were analyzed by QPCR. Mean values of viral recovery were 52, 42 and $49 \%$ respectively (Table 1). The NA extractions were preformed with QIAamp Viral RNA kit (Qiagen) for the samples (i) and (ii), and NucleoSpin ${ }^{\circledR}$ RNA Virus F kit (Machery \& Nagel, Dueren, Germany) for samples (iii).

For comparison of the SM-flocculation procedure with the two-step procedure, ten samples of $10-\mathrm{L}$ of artificial seawater were spiked with a suspension of $3.87 \times 10^{5} \mathrm{HAdV}$ GC and concentrated them by the glass wool method followed by organic flocculation. HAdV recoveries in the final concentrates were estimated by QPCR after NA extraction with QIAamp Viral RNA kit (Qiagen). The recovery obtained was $0.77 \%\left(0-3.34 \times 10^{3}\right.$ GC/10L). 


\subsection{Field study}

During the summer 2006 bathing season (June to September), 50 samples collected in the coast of the metropolitan area of Barcelona were analyzed by applying the SMflocculation procedure. The nucleic acid extraction procedure applied was NucleoSpin ${ }^{\circledR}$ virus F kit (Macherey \& Nagel) because only low levels of inhibitors were detected. The levels of inhibitors present in the final QPCR assays were evaluated by two procedures. One has been testing decimal dilutions of the spiked samples with HAdV and analyzing the quantity provided by the undiluted and diluted samples. The inhibition was identified if significant differences were observed in the concentration estimated in the respective dilution. Also low concentrations $\left(10^{3}\right.$ and $\left.10^{5} \mathrm{GC}\right)$ of the plasmid used as standard in QPCR assays were added to three representative samples in the QPCR reaction. The selected procedure for the field studies in the sampling site analyzed in this study was NucleoSpin ${ }^{\circledR}$ RNA Virus F kit (Machery \& Nagel, Dueren, Germany) allowing to concentrate $1 \mathrm{~mL}$ of the viral concentrate in $100 \mu \mathrm{L}$ of extracted NA. However seawater analyzed in other sampling sites presented higher concentration of inhibitors for the QPCR reactions and extraction of $200 \mathrm{~mL}$ of the viral concentrate using QIAamp viral RNA kit showed to be more efficient (data not shown). The volume of the viral concentrate tested in one PCR assay would correspond to $200 \mathrm{~mL}$ of the seawater sample. The samples were collected on 13 different sampling days (3-4 samples per day), two of them after rainfall events. In each sampling day, an extra sample was collected as a control of the process, theses samples were spiked with a suspension of adenoviruses and concentrated under the same conditions as the field samples. Moreover, artificial seawater samples were tested as negative control of methodology in each sampling day. 
The viral concentrates obtained were analyzed by nPCR and positive samples were further analyzed by QPCR and ICC-PCR. Six of seven positive samples were confirmed by sequencing. The levels of bacteriological indicators (IC and EC) also were tested on each sampling day.

From a total of 50 samples tested for HAdV seven samples were positive for HAdV using nPCR. Six samples were confirmed by sequencing: 4 samples were identified as HAdV 41 and 2 samples were identified as HAdV 31 with between 90 and $100 \%$ of homology with GenBank/EMBL databases entries. One of the positive samples was

confirmed to contain infectious HAdV 31 as tested by ICC-PCR (Reynolds et al., 1996). Moreover, 4 samples were quantified by QPCR obtaining mean values of $1.26 \times 10^{4}$ $\mathrm{GC} / 10 \mathrm{~L}\left(1.96 \times 10^{2}-3.48 \times 10^{4} \mathrm{GC} / 10 \mathrm{~L}\right)$. The levels of bacteriological indicators were high in the samples collected after rainfall event (mean values/100mL EC: $1.21 \times 10^{4}$ and IC: $6.25 \times 10^{3}$ ). However in samples collected during dry weather and found positive for HAdV the values for EC and IC complied with the actual directive for quality of bathing waters (EC: $<15-61 / 100 \mathrm{~mL}$ and IC: $<15-77 / 100 \mathrm{~mL})$. The turbidity in the samples was also measured (Hach Ratio/XR Turbidimeter) in each sampling day. The values detected were 1.56 to 28.00 NTU in normal days and 103.00 NTU in samples collected after rainfall event.

\subsection{Recovery rates of somatic coliphages from tap water and artificial seawater}

High concentrations of somatic coliphages are present in urban sewage and can be easily quantified by PFU (Plaque Forming Units) without the use of concentration protocols, for this reason somatic coliphages where used as a model to evaluate the concentration process in fresh and seawater. Ten samples of 9-L of either tap water or 
artificial seawater were seeded with $1 \mathrm{~L}$ of strained municipal raw wastewater. A total of $10 \mathrm{~L}$ of sample was immediately concentrated by glass wool filtration (first step) and organic flocculation (second-step). The somatic coliphages titre was determined before and after concentration by plaque assay. In the experiments using tap water, the glass wool retained $85 \%$ of the phage; however, it retained only $27 \%$ of the phage when artificial seawater was used. Recovery values represent the difference between the phage titre after concentration of the samples and the titre detected in the samples before filtration takes place.

\section{DISCUSSION}

Due to the poor recovery observed when evaluating the retention of HAdV and somatic coliphages in seawater by a two-step procedure, a new methodology for viral concentration in seawater samples has been explored in the present study. The recovery of the one-step procedure was determined to be 52 and $42-49 \%$ using QPCR assays for adenoviruses in artificial seawater and natural seawater samples respectively, whereas the glass-wool filtration procedure yielded a much poorer recovery of $0.77 \%$. Its poor performance in seawater seems to be a general phenomenon concerning many viruses as shown in the present study, the overall recovery of the heterogeneous somatic phage population present in wastewater also decreased in seawater. This effect is also in agreement with previously studies described by Lukasik et al., (2000). Apparently, the attachment of the viruses to the matrices, which in the first step is of electrostatic nature, is hampered by a high ionic strength and this would explain the low efficiency observed of adsorption-elution methods for the concentration of viruses from seawater (Lukasik et al., 2000). Experiments conducted to determine the time necessary for adenoviruses 
present in spiked samples to attach to skimmed milk flocs, indicate, as shown figure 1, that approximately five hours of stirring are needed for full attachment. However eight to ten hours of stirring are recommended to guarantee a maximum adsorption of viruses, permitting also process the samples overnight.

In preliminary studies for the selection of the nucleic acid extraction protocol diverse NA extraction kits were tested on viral suspensions obtained from cell culture supernatants and viral suspension in seawater with and without skimmed milk. The results indicate that presence of skimmed milk did not produce inhibition for the QPCR assay when using the two described nucleic acid extraction protocols (data not shown). The one-step procedure was further evaluated in a field study carried out in a coastal area near the metropolitan area of Barcelona. Using the developed method adenoviruses were quantified in samples with standard indicators complying with the Directive 2006/07/EC for quality of bathing waters and also in samples collected in rainfall days presenting higher values of bacterial standards. Turbidity was measured and viruses were detected in days presenting the higher turbidity levels 103 NTU but also in days showing the lower levels of turbidity (1.56 NTU). The relevance of these results is that the procedure is a useful tool for detecting contaminant HAdV, even in cases when the bathing site complies with the actual regulation for presence of bacteriological indicators. According to these results, the procedure described in present study would fulfil the conditions for a fitting method for routine public health laboratories: reproducible, reliability, straightforwardness and cost-effectiveness. 


\section{Acknowledgments}

'This work was partially supported by the EC Contract 513648, Project VIROBATHE; the "Xarxa de Referència de Biotecnologia de Catalunya and the Grup de Recerca Consolidat de la Generalitat de Catalunya 2005SGR00592. We thank David Kay for his contributions in the organization of the project and Jane Sellwood for supplying standard materials in the study. During the development of this study Byron Calgua was a fellow of the MAEC-ECID, Spanish Government (Ministerio de Asuntos Exteriores y Cooperación). We thank the Serveis Científico-Tècnics of the University of Barcelona for the very efficient sequencing services. 


\section{REFERENCES}

Albinana-Gimenez, N., Clemente-Casares, P., Bofill-Mas, S., Hundesa, A., Ribas, F., and Girones, R., 2006 Distribution of human polyomaviruses, adenoviruses, and hepatitis $\mathrm{E}$ virus in the environment and in a drinking-water treatment plant. Environ. Sci. Technol., 23, 7416-22.

Allard, A., Albinsson, B. and Wadell, G., 2001. Rapid typing of human adenoviruses by a general PCR combined with restriction endonuclease analysis, J. Clin. Microbiol. 39, 498-505

Bofill-Mas, S., Pina, S. and Girones, R., 2000. Documenting the epidemiologic patterns of polyomaviruses in human populations by studying their presence in urban sewage. Appl. Environ. Microbiol. 66, 238-245.

Bofill-Mas, S., Albinana-Gimenez, N., Clemente-Casares, P., Hundesa, A., Rodriguez-Manzano, J., Allard, A., Calvo, M., Girones, R., 2006. Quantitation and Stability of Human Adenoviruses and Polyomavirus JCPyV in Wastewater Matrices. Appl. Environ. Microbiol. 72, 7894-7896.

Carter, M. J., 2005. Enterically infecting viruses: pathogenicity, transmission and significance for food and waterborne infection. J Appl Microbiol. 6, 1354-80. 
Fong, T., and Lipp, E. K., 2005. Enteric viruses of humans and animals in aquatic environmental: health risks, detection, and potential water quality assessment tools. Microbiol. Mol. Biol. Rev. 69, 357-371.

Formiga-Cruz, M., Tofiño-Quesada, G., Bofill-Mas, S., Lees, D.N., Henshilwood, K., Allard, A.K., Condin-Hansson, A.-C., Hernroth, B.E., Vantarakis, A., Tsibouxi, A., Papapetropoulou, M., Furones, M.D., Girones, R., 2002. Distribution of human viral contamination in shellfish from different growing areas in Greece, Spain, Sweden and the United Kingdom, Appl. Environ. Microbiol. 68, 5990-5998.

Formiga-Cruz, M., Hundesa, A., Clemente-Casares, P., Albiñana-Gimenez, N., Allard, A., Girones, R., 2005. Nested multiplex PCR assay for detection of human enteric viruses in shellfish and sewage. J. Virol. Methods 125, 111-118.

Gerba, C. P., Goyal, S. M., LaBelle, R. L., Cech, I., Bodgan. G. F., 1979. Failure of indicator bacteria to reflect the occurrence of enteroviruses in marine waters. Am. J. Public Health 69, 1116-1119.

Goyal, S. M., Adams, W. N., O'Malley, M. L., Lear, D. W., 1984. Human pathogenic viruses at sewage sludge disposal sites in the Middle Atlantic region. Appl. Environ. Microbiol. 48, 758-763.

Griffin, D. W., Gibson, C. J., Lipp, E. K., Riley, K., Paul, J. H., Rose,J. B., 1999. Detection of viral pathogens by reverse transcriptase PCR and of microbial 
indicators by standard methods in the canals of the Florida Keys. Appl. Environ. Microbiol. 65, 4118-4125.

Griffin, D. W., Donaldson, K. A., Paul, J. H., Rose,J. B., 2003. Pathogenic human viruses in coastal waters. Clin. Microbiol. Rev. 16, 129-143.

Hernroth, B. E., Conden-Hansson, A. C., Rehnstam-Holm, A. S., Girones, R., Allard, A. K, 2002. Environmental factors influencing human viral pathogens and their potential indicator organisms in the blue mussel, Mytilus edulis: the first Scandinavian report. Appl. Environ. Microbiol. 68, 4523-4533.

Hundesa, A., Maluquer de Motes, C., Bofill-Mas, S., Albinana-Gimenez, N., Girones, R., 2006. Identification of human and animal adenoviruses and polyomaviruses for determination of sources of faecal contamination in the environment. Appl Environ Microbiol. 72, 7886-93.

ISO 7899-1, 1998. Water quality - Detection and enumeration of intestinal enterococci. Part 1: Miniaturized method (Most Probable Number) for surface and waste water.

ISO 9308-3. 1998. Water quality - Detection and enumeration of Escherichia coli and coliform bacteria. - Part 3: Miniaturized method (Most Probable Number) for the detection and enumeration of $E$. coli in surface and waste water. 
ISO 10705-2, 2000. Water quality - detection and enumeration of bacteriophages.

Part 2. Enumeration of somatic coliphages. International Organization for Standarization, Geneva, Switzerland.

ISO 19458, 2006. Water quality - Sampling for microbiological analysis. Guidance on planning water sampling regimes, on sampling procedures for microbiological analysis and on transport, handling and storage of samples until analysis begins.

Jiang, S., Noble, R., Chui, W. P., 2001. Human adenoviruses and coliphages in urban runoff-impacted coastal waters of Southern California. Appl. Environ. Microbiol. 67, 179-184.

Lipp, E. K., Jarrell, J. L., Griffin, D. W., Lukasik, J., Jacukiewicz, J., Rose, J. B., 2001. Preliminary evidence for human faecal contamination in corals of the Florida Keys. Mar. Pollut. Bull. 44, 666-670.

Lukasik, J., Scott, T. M., Andryshak, D., Farrah, S. R., 2000. Influence of salts on virus adsorption to microporous filters. Appl. Environ. Microbiol. 66, 2914-2920.

Noble, R. T., Fuhrman, J. A., 2001. Enteroviruses detected by reverse transcriptase polymerase chain reaction from the coastal waters of Santa Monica Bay, California: low correlation to bacterial indicator levels. Hydrobiologia 460, 175-184. 
Pina, S., Puig, M., Lucena, F., Cofre, J., Girones, R., 1998. Viral pollution in the environment and in shellfish: human adenovirus detection by PCR as an index of human viruses. Appl. Environ. Microbiol. 64, 3376-3382.

Reynolds, K. A., Gerba, C. P., Pepper, I. L., 1996 Detection of infectious enteroviruses by an integrated cell culture-PCR technique. Appl Environ Microbiol. $62,1424-1427$.

Vilaginès, P., Sarrette, B., Champsaur, H., Hugues, B., Dubrou, S., Joret, J.-C., Laveran, H., Lesne, J., Paquin, J. L., Delattre, J. M., Oger, C., Alame, J., Grateloup, I., Perrollet, H., Serceau, R., Sinègre, F., Vilaginès, R., 1997. Round robin investigation ofglass wool method for poliovirus recovery from drinking water and sea water. Water Sci. Technol. 35, 445-449.

Wolf, S., 2005, Evaluierung der hygienischen Wasserqualität unter besonderer Berücksichtigung von Bakteriophagen am Beispiel eines Tagebausees Dissertation, University of Dresden, Germany. 
Figure 1. Kinetics of the adsorption of HAdV to flocculated skimmed milk

Table 1. Recovery values of adenoviruses in seawater analyzed by SM-flocculation method.

\begin{tabular}{|c|c|c|c|}
\hline Sample ID & $\begin{array}{c}\text { HAdV added } \\
\text { GC/10L }\end{array}$ & $\begin{array}{c}\text { HadV recovered } \\
\text { GC/10L } \\
\end{array}$ & $\begin{array}{c}\text { Mean recovery } \\
\%\end{array}$ \\
\hline $\begin{array}{l}\text { AS1* } \\
\text { AS2* } \\
\text { AS3 } \\
\text { AS4 } \\
\text { AS5 }\end{array}$ & $4.04 \times 10^{4}$ & $\begin{array}{l}1.20 \times 10^{4} \\
3.53 \times 10^{4} \\
1.55 \times 10^{4} \\
2.73 \times 10^{4} \\
1.49 \times 10^{4}\end{array}$ & $51.98 \%$ \\
\hline $\begin{array}{l}\text { NS1"* } \\
\text { NS2"* } \\
\text { NS3"* } \\
\text { NS4" }\end{array}$ & $6.91 \times 10^{4}$ & $\begin{array}{l}3.33 \times 10^{4} \\
4.55 \times 10^{4} \\
3.28 \times 10^{4} \\
2.56 \times 10^{4}\end{array}$ & $42.53 \%$ \\
\hline $\begin{array}{l}\text { NS5 }^{* *} \\
\text { NS6"* } \\
\text { NS7"* } \\
\text { NS8"* } \\
\text { NS9* }\end{array}$ & $4.88 \times 10^{4}$ & $\begin{array}{l}1.68 \times 10^{4} \\
2.70 \times 10^{4} \\
4.08 \times 10^{4} \\
2.16 \times 10^{4} \\
1.42 \times 10^{4}\end{array}$ & $49.33 \%$ \\
\hline
\end{tabular}

${ }^{*}$ AS: Artificial seawater. ${ }^{* *}$ NS: Natural seawater 